\title{
Evaluation of a simple method of sampling the lung for quantitative histological analysis
}

\author{
M. S. D U N N I L L \\ From the Cardiopulmonary Laboratory, First Medical and Chest Services Columbia \\ University Division, Bellevue Hospital, New York City
}

In a previous paper (Dunnill, 1962), various quantitative methods were described for use in studying the pathological anatomy of the lung. These methods were developed from those used in the normal lung by E. R. Weibel, and their theoretical basis has been described fully by him (Weibel, 1963). An essential preliminary procedure was the selection of blocks of lung tissue to be sectioned for histological analysis, and a method of stratified random sampling was described. It is the purpose of this paper to assess the efficiency of this method in a series of samples from a normal and an emphysematous subject.

\section{MATERIAL AND METHODS}

Normal lungs were obtained from a woman, 55 years old, who died of a head injury in an automobile accident. There was no recognizable lung disease present. The abnormal lungs came from a woman of 60 years who suffered from a severe degree of centrilobular emphysema. The centrilobular spaces were scattered fairly uniformly throughout both lungs and accounted for $43 \%$ of the lung volume, as determined by the pointcounting method on the gross specimen (Dunnill, 1962). The lungs from both cases were treated in an identical manner. They were removed from the cadaver with extreme care to avoid puncturing the pleura and were then inflated with air to what was estimated as total lung capacity. The volumes of the inflated lungs were measured by water displacement, the mean of five measurements being taken. They were fixed with formalin steam by the method of Weibel and Vidone (1961) and allowed to float in Zenker's solution overnight.

The volumes of the fixed organs were then measured by water displacement. The determination of the fresh and the fixed volumes allowed for the calculation of a factor, $\mathrm{f}^{3}$, for the correc-

\footnotetext{
${ }^{1}$ Present address : Department of Pathology, The Radcliffe Infirmary, Oxford.
}

tion of fixed volumes to fresh volumes, the values $\mathrm{f}^{2}$ and $\mathrm{f}$ being the correction factors for area and linear measurements, respectively, on the assumption that shrinkage is equal in each dimension. In both these cases the value of $f^{3}$ was $1 \cdot 82$. The lungs were then cut through the hilum into a series of $1 \mathrm{~cm}$. thick parallel slices. The volume of the parenchyma, as opposed to the nonparenchyma consisting of blood vessels and airways greater than $0.1 \mathrm{~cm}$. in diameter, was determined by the simple point-counting method described by Dunnill (1962). The slices were placed side by side on a flat surface and each slice was covered completely with a piece of cellophane on which was drawn a grid composed of squares of side $1 \mathrm{~cm}$. The corners of each square were perforated so that the resulting hole would admit a pin head. The squares were numbered consecutively. If 20 blocks were required and 10 slices were present, the first square was selected by means of the random number table and the second square by addition of a constant number to the chosen random number.

This procedure avoids the unlikely, but possible, event of sampling two adjacent areas which might occur with pure random sampling employing no system of stratification. Furthermore. blocks from the hilum must be excluded because large bronchi and blood vessels are present and there is little or no parenchyma. When a square had been selected a pin was passed through the perforation at the top left-hand corner of the square, and, when all the squares had been chosen, the grids were removed, leaving the pins in situ. Blocks of tissue were cut out of the lung with the pin placed arbitrarily at the top left-hand corner of the block. The size of the blocks was kept as uniform as possible, $2.8 \times 2.0 \times 1.0 \mathrm{~cm}$. being found to be convenient. Each block was measured, processed, and embedded in paraffin, and sections were cut at $5 \mu$ thickness. The sections were stained by the Masson trichrome or P.A.S. methods. One section from each block was used for the subsequent histo- 
logical measurements. The area occupied by the sections on the slide was measured, and this, when compared with the area of the cut surface of the fixed block, gave a factor for converting areas of processed tissue to fixed tissue. From this factor, $\mathrm{p}^{2}$, similar factors, $\mathrm{p}^{3}$ for volume and $\mathrm{p}$ for linear dimensions, were calculated.

\section{HISTOLOGICAL ANALYSIS}

Volume proportions The volume proportions of the alveolar air, respiratory duct air, tissue, and vessels were determined, using the point-counting integrating eyepiece of Zeiss (Hennig, 1958). This method has been fully described in a previous paper (Dunnill, 1962). Five hundred points were counted on each slide, using the low power of the microscope, and these were found to cover the entire section.

Number of alveoli The method used was that described by Weibel and Gomez (1962 a). In the normal lung, the alveolar transections were counted in 10 fields on each slide. The fields were outlined by a square grating drawn on an eyepiece graticule. In the normal lung the area of the square was $9.08 \times 10^{-3} \mathrm{~cm}^{2}$ In the abnormal lung, a slightly different graticule was used with an area of $9 \cdot 13 \times 10^{-3} \mathrm{~cm} .^{2}$ The method is fully described in the original paper. The number of alveoli, $\mathrm{N}$, in a unit volume is given by

$$
\mathrm{N}=\frac{\mathrm{n}^{3 / 2}}{\beta \sqrt{ } \rho}
$$

where $\mathrm{n}$ is the number of alveolar transections in a unit area, $\rho$ is the volume proportion of alveoli, and $\beta$ is a shape constant which for normal alveoli was estimated by Weibel and Gomez to have a value of 1.55.

Alveolar surface area The mean linear intercept method of Campbell and Tomkeieff (1952) and Hennig (1956) was employed. Crossed hair lines, each measuring $0.235 \mathrm{~cm}$., were placed on 10 fields on each section of both normal and abnormal lungs, and the number of intercepts with respiratory tissue was counted. The mean linear intercept, $\mathrm{L}_{\mathrm{m}}$, was then calculated from the number of intercepts, $\mathrm{m}$, the length of the line, $0.235 \mathrm{~cm}$., and the number of times the line was placed on the sections, $\mathbf{N}$, from

$$
\mathrm{L}_{\mathrm{m}}=\frac{0.235 \mathrm{~N}}{\mathrm{~m}}
$$

The alveolar surface area, $S$, then follows from

$$
\mathrm{S}=\stackrel{4 \mathrm{~V}}{=\overline{\mathrm{L}}}
$$

where $\mathrm{V}$ is the volume of the processed lung parenchyma. This value for $S$ has then to be multi- $\overline{\frac{D}{D}}$ plied by the factor converting processed areas to $\vec{\sigma}$ fresh areas, $\mathrm{p}^{2} \mathrm{f}^{2}$, which in both these cases was $1 \cdot 82$.

SELECTION OF MICROSCOPIC FIELDS FOR HISTOLOG ICAL ANALYSIS The selection of fields in which to $\vec{\omega}$ count the number of alveolar transections or the number of intercepts presents a problem similar $x$ to that of the selection of blocks on the gross $\overrightarrow{0}$ specimen. In order to obtain a representative and $r$ unbiased selection of fields, a random sampling $\vec{\omega}$ procedure was adopted. The vertical and horizon- $\omega$ tal micrometer gauges on the mechanical stage of the microscope were employed together with a $\vec{c}$ table of three digit random numbers. These $\mathbb{D}$ numbers were used to give references on the $\frac{\vec{D}}{\mathbb{D}}$ horizontal and vertical gauges, and by this method 10 fields were easily selected.

\section{RESULTS AND DISCUSSION}

The estimates for the number of alveoli and for the alveolar surface area, in both the normal and the abnormal lung, are given in Table I. It is

TABLE I

\begin{tabular}{|c|c|c|c|c|c|}
\hline & & & & $\begin{array}{l}\text { Normal } \\
\text { L.ung }\end{array}$ & $\begin{array}{c}\text { Abnormal } \\
\text { Lung }\end{array}$ \\
\hline \multirow{3}{*}{\multicolumn{4}{|c|}{$\begin{array}{l}\text { Volume of fresh lung at T.L.C. (ml.) } \\
\text { Volume of fixed lung } \\
\text { Conversion factor for fixed to fresh tissue } \\
\text { (volume) }\end{array}$}} & 6,450 & 4,825 \\
\hline & & & & 3,550 & 2,650 \\
\hline & & & & $1 \cdot 82$ & $1 \cdot 82$ \\
\hline \multicolumn{4}{|c|}{$\begin{array}{l}\text { Percentage volume of non-parenchyma } \\
\text { Conversion factor for fixed to processed }\end{array}$} & $7 \cdot 75$ & $7 \cdot 00$ \\
\hline \multicolumn{4}{|c|}{ tissue (volume) } & $0 \cdot 75$ & 0.75 \\
\hline \multirow{2}{*}{\multicolumn{4}{|c|}{$\begin{array}{l}\text { Volume of processed parenchyma (ml.) } \\
\text { Conversion factor for processed to fresh }\end{array}$}} & 2,463 & 1,848 \\
\hline & & & & & \\
\hline Total number of alveoli & $\begin{array}{l}\cdots \\
\ldots\end{array}$ & $\begin{array}{ll}\cdots \\
.\end{array}$ & tissue (area) & $\begin{array}{c}1.82 \\
286 \cdot 10^{6}\end{array}$ & $94 \cdot 10^{6}$ \\
\hline Total surface area $\left(\mathrm{m}^{2}\right)$ & & & & $75 \cdot 8$ & $39 \cdot 1$ \\
\hline \multirow{2}{*}{\multicolumn{4}{|c|}{ Volume proportions (percentages) }} & & \\
\hline & & & & $55 \cdot 64$ & $40 \cdot 84$ \\
\hline Respiratory duct air & & . & & $36 \cdot 83$ & 15.30 \\
\hline Abnormal air space air & & & & $\overline{0}$ & $30 \cdot 49$ \\
\hline Tissue $\quad \ldots \quad \ldots$ & & & & $6 \cdot 29$ & $11 \cdot 49$ \\
\hline Vessels $\quad \ldots \quad \ldots$ & & .. & & $1 \cdot 24$ & 1.88 \\
\hline \multicolumn{4}{|c|}{ Mean no. of alveolar transections per field } & $23 \cdot 810$ & $12 \cdot 482$ \\
\hline Mean no. of intercepts per & fiel & 2 & & $19 \cdot 875$ & $13 \cdot 690$ \\
\hline
\end{tabular}

SUMMARY OF DATA ON NORMAL AND ABNORMAL LUNGS

important to establish (1) that there is a significante variation between slides with regard to the number of alveolar transections and number of intercepts $; \stackrel{+}{+}$ (2) that there is a significant variation between

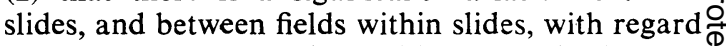
to the volume proportions ; $(3)$ the standard errors of the volume proportions, the number $\mathrm{cf} \stackrel{\mathbb{Q}}{\Omega}$ alveolar transections and the number of intercepts: 
and (4) what the standard error would be if the number of samples were smaller, as clearly it would be a great advantage if a reasonable estimate of these components of lung structure could be made on relatively few samples of tissue.

A model has been used where the observation in the $\mathrm{j}^{\text {th }}$ field of the $\mathrm{i}^{\text {th }}$ slide is given by

$$
\mathrm{y}_{\mathrm{ij}}=\mu+\mathrm{a}_{\mathrm{i}}+\mathrm{e}_{\mathrm{ij}} \quad(\mathrm{i}=1, \ldots \mathrm{I} ; \mathrm{j}=1, \ldots \mathrm{J})
$$

where the sets $a_{i}$ and $e_{i j}$ are independent random variables with zero means. The as are identically distributed with variance $\sigma_{s}{ }^{2}$, the $\mathrm{e}_{i j} \mathrm{~s}$ are identically distributed with variance $\sigma_{\mathrm{e}}{ }^{2} ; \mathrm{a}_{\mathrm{i}}$ is thus the component of variance between slides and $e_{i j}$ the residual variance. For the significance tests the $a_{1} s$ and the $e_{i j} s$ are assumed to be normally distributed. This will give rise to the following component variance analysis.

\begin{tabular}{|c|c|c|c|}
\hline Source & $\begin{array}{l}\text { Degrees of } \\
\text { Freedom }\end{array}$ & $\begin{array}{l}\text { Sum of } \\
\text { Squares }\end{array}$ & $\begin{array}{c}\text { Estimated Mean } \\
\text { Square }\end{array}$ \\
\hline Between slides & I - 1 & $\sum_{i=1}^{I} \frac{Y_{i}^{2}}{J}-\frac{Y_{.}^{2}}{I J}$ & $\begin{array}{c}\sigma_{\mathrm{e}}^{2}+\mathrm{J} \sigma_{\mathrm{s}}^{2} \\
2\end{array}$ \\
\hline Residue & $\mathbf{I}(\mathrm{J}-1)$ & $\Sigma y_{i j}^{2}-\frac{\Sigma Y_{i}^{2}}{J}$ & $\sigma_{\mathrm{e}}^{2}$ \\
\hline Total $\quad . \quad \ldots$ & IJ -1 & $\Sigma y_{i j}^{2}-\frac{Y_{.}^{2}}{I J}$ & \\
\hline
\end{tabular}

The standard error, $\sigma_{\bar{y}}$, of the population mean, $\bar{y}$, will be given by

$$
\sigma_{\overline{\mathrm{y}}}=\sqrt{\frac{1}{\overline{\mathrm{I}} \mathbf{\mathrm { J }}}\left(\sigma_{\mathrm{e}}{ }^{2}+\mathrm{J}_{\sigma_{\mathrm{s}}}{ }^{2}\right)}
$$

This relationship can be used to determine the standard error of the mean in any experiment where I blocks of tissue (slides) are taken and J fields counted on each slide.

In the normal lung, the differences between slides are unlikely to be very great due to the uniformity of parenchymal structure in the normal organ. The analysis of variance with respect to the number of alveolar transections illustrates this point.

\begin{tabular}{r|c|c|c}
\hline Source & $\begin{array}{c}\text { Degrees of } \\
\text { Freedom }\end{array}$ & $\begin{array}{c}\text { Sum of } \\
\text { Squares }\end{array}$ & $\begin{array}{r}\text { Mean } \\
\text { Square }\end{array}$ \\
\hline $\begin{array}{c}\text { Between slides } \\
\text { Residue .. . }\end{array}$ & 19 & $\begin{array}{r}148 \cdot 38 \\
2890 \cdot 40\end{array}$ & $\begin{array}{r}7 \cdot 809 \\
16.058\end{array}$ \\
\hline Total .. & 199 & $3038 \cdot 78$ & \\
\hline
\end{tabular}

This gives a value for Residual mean square/ Between slides mean square of 2.056 . This seems to indicate that the differences between slides are less than those between fields within slides. However, since the significance level is only that of $5 \%$, or 1 in 20 , no great importance should be placed on this result. This means that there is no significant difference between slides. In this case, as the values for the residual mean square exceed the between slides mean square, the larger mean square has been used to estimate the standard error of the mean. Equation (5) then becomes

$$
\sigma_{\bar{y}}^{-}=\sqrt{\frac{1}{\overline{\mathbf{I J}} \sigma_{\mathrm{e}}^{2}}}
$$

The estimate of the population mean of alveoli per field is 23.81 with a standard error of 0.28 , or approximately $1 \cdot 2 \%$. Clearly, in the normal lung, a far smaller number of blocks would give an adequate estimate. It can be seen that with five blocks of tissue (slides) and 10 fields per slide the standard error would still be only of the order of $2 \%$.

In the case of the number of intercepts per field in the normal lung, the analysis of variance is given below, showing that there is no significant difference between slides. The value for Residual

\begin{tabular}{c|c|c|c}
\hline \multicolumn{1}{c|}{ Source } & $\begin{array}{c}\text { Degrees of } \\
\text { Freedom }\end{array}$ & $\begin{array}{c}\text { Sum of } \\
\text { Squares }\end{array}$ & $\begin{array}{c}\text { Mean } \\
\text { Square }\end{array}$ \\
\hline $\begin{array}{c}\text { Between slides } \\
\text { Residue }\end{array}$ & 19 & $\begin{array}{c}167 \cdot 8 \\
1,960 \cdot 1\end{array}$ & $\begin{array}{c}8 \cdot 83 \\
10 \cdot 89\end{array}$ \\
\hline Total $\ldots$ & 180 & $2,127 \cdot 9$ & \\
\hline
\end{tabular}

mean square/Between slides mean square is 1.233 , which is not significant. The estimate of the mean number of intercepts per field is 19.875 with a standard error of $\mathbf{0 \cdot 2 3 3}$. Five slides and 10 fields per slide would give an error of 0.467 or $2.3 \%$.

In the emphysematous lung there is a much

\begin{tabular}{|c|c|c|c|}
\hline Source & $\begin{array}{l}\text { Degrees of } \\
\text { Freedom }\end{array}$ & $\begin{array}{l}\text { Sum of } \\
\text { Squares }\end{array}$ & $\begin{array}{l}\text { Mean } \\
\text { Square }\end{array}$ \\
\hline $\begin{array}{l}\text { Between slides } \\
\text { Residue }\end{array}$ & $\begin{array}{r}39 \\
360\end{array}$ & $\begin{array}{r}3,559 \cdot 18 \\
16,903 \cdot 70\end{array}$ & $\begin{array}{l}91 \cdot 261 \\
46.955\end{array}$ \\
\hline Total & 399 & $20,462 \cdot 88$ & \\
\hline
\end{tabular}
greater difference between slides, as is shown by the analysis of variance for alveolar transections.

This gives a value for $F$ of 1.94 , which shows that there is a significant difference between slides at the $0.5 \%$ level. The mean number of alveolar transections per field is 12.482 and, using equation (5), the standard error is 0.470 or approximately 
$3.8 \%$. If, say, 10 slides were chosen, then the error would be 0.95 or $7.6 \%$.

A similar analysis of variance for the number of intercepts per field is given below.

\begin{tabular}{|c|c|c|c|}
\hline Source & $\begin{array}{l}\text { Degrees of } \\
\text { Freedom }\end{array}$ & $\begin{array}{l}\text { Sum of } \\
\text { Squares }\end{array}$ & $\begin{array}{l}\text { Mean } \\
\text { Square }\end{array}$ \\
\hline $\begin{array}{l}\text { Between slides } \\
\text { Residue }\end{array}$ & $\begin{array}{r}39 \\
360\end{array}$ & $\begin{array}{l}1,709 \cdot 96 \\
9,174 \cdot 60\end{array}$ & $\begin{array}{l}43 \cdot 845 \\
25 \cdot 485\end{array}$ \\
\hline Total & 399 & $10,884 \cdot 56$ & \\
\hline
\end{tabular}

This gives an $\mathrm{F}$ value of $1 \cdot 72$, which shows there is a significant difference between slides at the $1 \%$ level. The standard error of the mean number of intercepts per field, 13.69 , is 0.331 or $2.4 \%$. If 10 fields on each of 10 slides were sampled, this would give a standard error of 0.66 or $4.8 \%$.

The greater error found when dealing with the numbers of alveoli, as opposed to the numbers of

TA B LE I I

ANALYSIS OF VARIANCE FOR ALVEOLAR AIR IN EMPHYSEMATOUS LUNG

\begin{tabular}{|c|c|c|c|c|}
\hline Source & $\begin{array}{l}\text { Degrees } \\
\text { of } \\
\text { Freedom }\end{array}$ & $\begin{array}{c}\text { Sum } \\
\text { of } \\
\text { Squares }\end{array}$ & $\begin{array}{l}\text { Mean } \\
\text { Square }\end{array}$ & $F$ \\
\hline $\begin{array}{c}\text { Between } \\
\text { slides } \\
\text { Between } \\
\text { fields } \\
\text { (within } \\
\text { slides) } \\
\text { Residue }\end{array}$ & $\begin{array}{r}160 \\
19,800\end{array}$ & $\begin{array}{r}107 \cdot 288 \\
4,610 \cdot 450\end{array}$ & $\begin{array}{l}0.6706 \\
0.23285\end{array}$ & 4.47 \\
\hline Total & 19,999 & $4,832 \cdot 006$ & & \\
\hline
\end{tabular}

The $F$ values show that the variance between slides, and between fields within slides, are both significant at the $0.1 \%$ level.

The estimate of the proportion is 0.40835 with a standard error of 0.0121 .

$$
\begin{aligned}
& \sigma_{\mathrm{e}}^{2}=0.23285 \\
& \sigma_{\mathrm{f}}^{2}=0.00438 \\
& \sigma_{\mathrm{s}}^{2}=0.00452
\end{aligned}
$$

TABLE II I

\begin{tabular}{|c|c|c|c|c|}
\hline Source & $\begin{array}{l}\text { Degrees } \\
\text { of } \\
\text { Freedom }\end{array}$ & $\begin{array}{c}\text { Sum } \\
\text { of } \\
\text { Squares }\end{array}$ & $\begin{array}{l}\text { Mean } \\
\text { Square }\end{array}$ & $\mathrm{F}$ \\
\hline 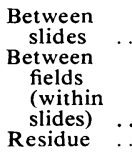 & $\begin{array}{r}160 \\
19,800\end{array}$ & $\begin{array}{r}40 \cdot 048 \\
2,519 \cdot 270\end{array}$ & $\begin{array}{l}0.2503 \\
0.1272\end{array}$ & 3.401 \\
\hline Total & 19,999 & $2,592 \cdot 514$ & & \\
\hline
\end{tabular}

ANALYSIS OF VARIANCE FOR ALVEOLAR DUCT AIR IN EMPHYSEMATOUS LUNG

The $\mathrm{F}$ values show that the differences between slides, and between fields within slides, are both significant at the $0 \cdot 1 \%$ level. The estimate of the proportion is 0.15305 and the standard error is 0.0065 .

$$
\begin{aligned}
& \sigma \mathrm{e}^{2}=0.12723 \\
& \sigma^{2}=0.00123 \\
& \sigma_{*}^{2}=0.00120
\end{aligned}
$$

intercepts, is due to the great variation in shapeand size of the normal alveoli in an emphy sematous lung and also to the difficulty of identify ing, with certainty, all the normal alveoli in a given area on a given section of lung.

An analysis of variance can be applied to the estimate of the volume proportions. In the normal lung the differences within slides and betweencw slides are not significant. In the emphysematous lung this is not so. In this case, 20,000 points were counted on 40 slides. The position of each point $\overrightarrow{0}$ was assessed, and the points were recorded inor fields of 100 points. Thus, every 100 points, the number lying in each of the components, alveolar air, alveolar duct air, abnormal air space air,, tissue, and vessels was listed. There were five fields for each slide. The analysis of variance ford

\begin{tabular}{|c|c|c|c|c|}
\hline Source & $\begin{array}{l}\text { Degrees } \\
\text { of } \\
\text { Freedom }\end{array}$ & $\begin{array}{c}\text { Sum } \\
\text { of } \\
\text { Squares }\end{array}$ & $\begin{array}{l}\text { Mean } \\
\text { Square }\end{array}$ & $\mathrm{F}$ \\
\hline $\begin{array}{c}\text { Between } \\
\text { slides } \\
\text { Between } \\
\text { fields } \\
\text { (within } \\
\text { slides) } \\
\text { Residue }\end{array}$ & $\begin{array}{r}160 \\
19,800\end{array}$ & $\begin{array}{l}175 \cdot 2760 \\
3,832 \cdot 68\end{array}$ & $\begin{array}{l}1.0955 \\
0.19357\end{array}$ & $5 \cdot 40$ \\
\hline Total & 19,999 & $4,238 \cdot 7198$ & & \\
\hline
\end{tabular}
alveolar air, alveolar duct air, and abnormal air space air is given in Tables II, III, and IV.

T A B LE I V ANALYSIS OF VARIANCE FOR ABNORMAL AIR SPACE AIR

The $F$ values show that the variance between slides, and betue fields within slides, are both significant at the $0.1 \%$ level.

The estimate of the proportion is 0.3049 with a stardard error 0.0172 .

$$
\begin{aligned}
& \sigma_{\mathrm{e}}^{2}=0.19357 \\
& \sigma_{\mathrm{f}}^{2}=0.00902 \\
& \sigma_{\mathrm{s}}{ }^{2}=0.00964
\end{aligned}
$$

A model for the analysis of variance for pro- $\delta$ portions of lung tissue was used where the observation of the $\mathrm{k}^{\text {th }}$ point in the $\mathrm{j}^{\text {th }}$ field of the $\mathrm{i}^{\text {th }}$ 윽 slide was given by

$$
\begin{gathered}
y_{i j k}=\mu+a_{i}+b_{i j}+e_{i j k} \\
\left(i=1, \ldots I_{j} \quad j=1, \ldots J \quad k=1, \ldots K\right)
\end{gathered}
$$

were $\mu$ is the overall mean, $a_{i}$ is the between slides $N$ effect, $b_{i j}$ is the between fields within slides effect, 0 and $e_{i j \mathrm{k}}$ is the residual term. $y=1$ when the point 0 lies in the component being estimated, e.g., $\stackrel{\overparen{D}}{\mathscr{D}}$ alveolar air, duct air, etc., and $\mathrm{y}=0$ otherwise. $\stackrel{\mathcal{Q}}{+}$ The $a_{i} s, b_{i j} s$, and $e_{i j k} s$ are all independently 0 distributed with zero means; the $\mathrm{a}_{\mathrm{i}} \mathrm{s}$ identically with variance $\sigma_{s}{ }^{2}$, the $b_{i j}$ s identically with variance $\stackrel{D}{\stackrel{D}{D}}$ $\sigma_{\mathrm{F}}{ }^{2}$, and the $\mathrm{e}_{\mathrm{ijk}} \mathrm{s}$ identically with variance $\sigma_{\mathrm{e}}{ }^{2} \cdot \stackrel{\mathbb{D}}{\mathbb{Q}}$ For the significance tests these variates are also 
TABLE V

\begin{tabular}{|c|c|c|c|}
\hline Source & $\begin{array}{l}\text { Degrees of } \\
\text { Freedom }\end{array}$ & Sum of Squares & $\begin{array}{c}\text { Expected Mean } \\
\text { Square }\end{array}$ \\
\hline $\begin{array}{c}\text { Between } \\
\text { slides }\end{array}$ & I - 1 & $\sum_{i=1}^{I} \frac{Y_{i} \ldots}{J K}-\frac{Y_{\ldots}^{2}}{I J K}$ & $\sigma_{\mathrm{e}}^{2}+\mathrm{K} \sigma_{\mathrm{z}}^{2}+\mathrm{JK} \sigma_{\mathrm{s}}^{2}$ \\
\hline $\begin{array}{l}\text { Between } \\
\text { fields } \\
\text { (within } \\
\text { slides) }\end{array}$ & $\mathrm{I}(\mathrm{J}-1)$ & $\sum_{i=1}^{I} \sum_{j=1}^{J} \frac{Y_{i j}^{2}}{K}-\sum_{i=1}^{I} \frac{Y_{i}^{2} \ldots}{J K}$ & $\sigma_{e}^{2}+K \sigma_{r}^{2}$ \\
\hline Residue & $1 \mathrm{~J}(\mathrm{~K}-1)$ & $\underset{i=1}{\sum} \sum_{j=1}^{J} \sum_{k=1}^{K} y_{i j k}^{2}-\sum_{i=1}^{I} \sum_{j=1}^{J} \frac{Y_{i j .}^{2}}{K}$ & $\sigma_{\mathrm{e}}^{2}$ \\
\hline Total & IJK - 1 & $\sum_{i=1}^{I} \sum_{j=1}^{J} \sum_{k=1}^{K} y_{i j k}^{2}-\frac{Y_{\ldots}^{2}}{I J K}$ & \\
\hline
\end{tabular}

important of these is the variation in shape of the remaining normal alveoli in this disease. In those areas adjacent to the centrilobular spaces, the normal alveoli may be distorted or different in size from those present in normal lung.

In deciding the number of blocks to be taken in any given case, the construction of a summation average graph may be of great assistance. This entails calculating the mean of, say, the number of alveolar transections after each field has been counted. One such graph for a normal lung is illustrated in Fig. 1. It can be seen that for the first few observations the mean oscillates considerably, but that after a number of observations, in this case 50, corresponding to five slides, the mean remains steady within very narrow limits. In emphysematous cases the mean takes longer to reach its steady value. When this steady state has component variance is shown in Table V. In such a model with a random sample of I slides, $J$ fields per slide, and $K$ points per field, the standard error, $\sigma_{\rho}$, of the volume proportion, $\rho$, is given by

$$
\sigma_{\rho}=\sqrt{\frac{1}{\mathrm{IJK}}\left(\sigma_{\mathrm{e}}{ }^{2}+\mathrm{K}{\sigma_{\mathrm{F}}}^{2}+\mathrm{JK}{\sigma_{\mathrm{s}}}^{2}\right)}
$$

Thus it is possible to calculate the standard error of the volume proportions of the various components if, say, only 10 blocks of tissue had been selected. Assuming 100 points were counted per field, and there were five fields per slide, the standard errors for the proportions of alveolar air, duct air, and abnormal air space air would be $0.024,0.013$, and 0.034 respectively.

It can be seen that with as few as five blocks of tissue in the normal lung and 10 blocks in the abnormal lung a fairly accurate estimate of quantitative anatomical data can be obtained. In the normal lung the final values for the number of alveoli and for the alveolar surface area are in good agreement with those of Weibel and Gomez $(1962 \mathrm{~b})$. The figures for the number of alveolar transections and for the number of intercepts, together with their corresponding analyses of variance, illustrate well the uniformity of the normal lung parenchyma.

In the emphysematous lung the mean linear intercept method is particularly reliable when used with this method of sampling. This is because it is independent of the size, shape, and configuration of the structures whose total surface area is being estimated. The greater variation in the estimation of the numbers of alveoli in this lung is due to a combination of factors. Probably the most

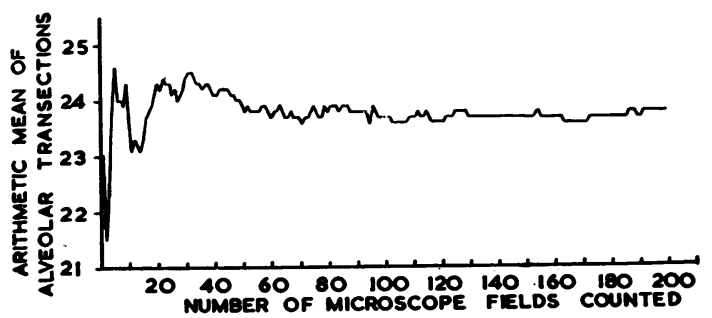

FIG. 1. A summation average graph plotted for the alveolar transections of the normal lung. It can be seen that after 50 fields have been counted, i.e., five slides, the mean varies very little, in fact less than 0.3 .

been achieved, there is little point in continuing the observations as these will not alter the mean significantly.

The results shown here indicate that it is possible to obtain reliable quantitative data in pathological lungs with relatively few blocks of suitably selected and prepared tissue. This fact is likely to be of considerable importance in the correlation of pathology with respiratory function tests performed during life. In the future it is hoped that similar methods of sampling may be used in the quantitative morphological analysis of other organs.

\section{SUMMARY}

A simple method for sampling the lung for quantitative morphological analysis is described and evaluated. It employs the principle of random sampling and gives a representative picture of 
pathological lungs with the selection of relatively few blocks of tissue. Two examples are given, one a normal lung and the other a lung from a case of diffuse centrilobular emphysema.

It is a pleasure to acknowledge the stimulating interest and help of Dr. E. R. Weibel and the interest of Drs. André Cournand, Dickinson W. Richards, and D. M. Gomez. I am especially grateful to Mr. J. Anderson, of the Unit of Biometry, Oxford, for help with the statistical analysis.

This work was supported by grants from the Health Research Council of the City of New York, the United States Public Health Service (USPHS-H5741(R1) and the New York Heart Association.

\section{REFERENCES}

Campbell, H., and Tomkeieff, S. I. (1952). Calculation of the interna 1 surface of a lung. Nature (Lond.), 170, 117.

Dunnill, M. S. (1962). Quantitative methods in the study of pulmonary pathology. Thorax, 17, 320 .

Hennig. A. (1956). Bestimmung der Oberfläche beliebig geformter Körper mit besonderer Anwendung auf Körperhaufen im mikrosk opischen Bereich. Mikroskopie, 11, 1.

- (1958). Kritische Betrachtungen zur Volumen und Oberflächenmessung in der Mikroskopie. Zeiss Werkzeitschr, 6, 78.

Weibel, E. R. (1963). Principles and methods for the morphometric study of the lung and other organs. Lab. Invest., 12, 131.

—- and Gomez, D. M. (1962a). A principle for counting tissue structures on random sections. J. appl. Physiol., 17, 343.

(1962b). Architecture of the human lung. Science, 137, 577. and Vidone, R. A. (1961). Fixation of the lung by formalin steam in a controlled state of air inflation. Amer, Rev. resp. Dis., 84, 856 . 